\title{
An Anthropological-Institutional Overview of Communism and Political Pluralism in Albania
}

\author{
Ass. Prof. Dr. Përparim Kabo \\ Senior lecturer in "Mesdhetar"University; Dean at the Law \& \\ Political Sience Faculty teaching in the double-major of Social Anthropology and Globalization
}

\section{Doi:10.5901/ajis.2017.v6n1p97}

\section{Abstract}

The individual in communism was deformed from extreme collectivism and sterilizing ideology! The service toward the cause of communism on this individual was engrafted with a feeling of love for the regime. In these circumstances was created "idolideology" and "ddol-leadership." This kind of morality and education shaped and mal-nurtured the isolated and submissive individual, a politicized one; the individual that considered himself as a member of the armada with epochal historical mission. The communist system of "Popular Democracy," resurrected the ancient feature of our anthropology built during the ruling of the Ottoman Empire period: "serving and being under command!" So much as the individuals entered into a race with oneanother to serve the Party, and in hierarchic order from bottom-up, to serve directly the leadership, even more the main leader. This type of competition was complete with the vice, because of the cultural differences, the routine part of anthropology acted upon the lead of a negative energy, materialized through: lies, slander, intrigues, traps, unfaithfulness, and hate. Serventhood reawakened the ottoman mechanism of serving and faithfulness on family basis, family heritage, on kinship, regionally and nepotistic relationships. The long absence of freedom, as a natural social breathing, as a co-existential instrumental mechanism that widens the spectrum of legal action, the purpose of which is the respect for human rights and their realization with main feature the human dignity and prosperity, nevertheless could not have left traces upon the individual and collective conscience. The elongated historical authoritarianism and the permanent absence of democratic system, the fearful isolation in communism, the absence of any private property, the absence of the freedom of speech: including the religious one, had shaped the Albanian anthropologic-individual deeply deformed and totally unprepared for liberal democracy. All of this situation made the anarchy to be displayed as form of weakness to be oriented. Anthrop-anarchy was created as a transitional form of anthropological groups, which left behind the classical and ideological forms of the organization in communism, and in contact with the free-market economy, with the freedom of movements, with the open society for change; being an unprepared anthropology and lead by incompetent policy-making, occurred that these anthropological groupings to take intermediate forms, illusive traits, unstable structures. Anthrop-anarchy entered in a battle to be legalized by bending the state in its knees, which by its decisions legalized the informality: property and economic wise. So, the footpath was opened for the anarchic individual, who appeared as promoter of the Albanian society in transition. Politics accepted this pressure, because they continue to count their votes. Differently from all of the former Eastern Communist countries, Albania is the only one that has informal property problems in national level. The authoritative power has more dispositions to legalize the informal properties, rather than support by law the legal owners. There are more than 300,000 informal buildings that have been included in the legalization process. This informal reality with national dimensions, shows that in Albania still it is not understood that private property is 9/10 law and $1 / 10$ asset. This is an assassination against the legal statehood. This situation helps to understand why the "democracy through law" does not function. The political parties have morphed in market accessories. Even worse, this mechanism has changed into a system, therefore in Albania there are no poor politicians. Another feature of political party pluralism is the absence of political relativism. The parties sell their ideas and programs as an absolute truth. In these political climate is impossible the function the cultural political pluralism. This is why, the democracy in Albania cannot be considered as functional or simply fragile one. That is an authoritarian democracy that is fed by the exclusiveness philosophy, and that creates conflictual actions, that often end "beheaded" by Ottoman style! It is necessary that the change to create a liberal democracy system must start from education on law, rules, and constitutionality. We must cross the bridge from an Oriental inherited education to a Western Civilization one!

Keywords: Communism, ideology, freedom, human dignity, anarchy, anthropology, the existence of dissident, incompetent policy-making, legalized the informality, society in transition, informal property, democracy through law, political relativism, functional in Albania, cultural political pluralism, conflictual actions, liberal democracy, Ottoman style and education on law, Oriental inherited and functional democracy 


\section{The Specific Features of Communism in Albania}

Unlike many of the former communist countries of Eastern Europe, Albanian communism and transition have some peculiarities related to its historic development.

The fall of communism was not preceded by the existence of dissident individuals and groups at home or abroad! "Albania did not have a Lech Walesa, an Arpad Genz, or a Vaclaf Havel. The communist regime had done short work of the old intelligentsia, artists and writers, the military elite, and any other "individual knight".

Therefore, Albanian communism came down to the beginning of the 90s of last century with a wholly radical Stalinist physiognomy. The Party of Labor of Albania did not recognize the Gomulka phenomenon and the events in Poland, or the Hungarian phenomenon of the democratic movement of 1956. Despite the $20^{\text {th }}$ Congress of the Communist Party of the Soviet Union and Nikita Khrushchev's secret speech on the crimes and atrocities of Stalin's time and the "Personality Cult" in the party and in the state management, the Party of Labor of Albania (PPSH) did not commit itself to softer policies and to "broadening the freedom" within the communist system, which came to be known as modern revisionism. On the contrary, the PPSH nipped in the bud any attempts made even to criticisms the highest ranking leadership, as the case was in the Tirana Party Conference in 1956.

Communism with its dogma and moralizing slogans homogenized the Albanian society, underlining the national interests and the nation's endangered destiny. In Communist Albania, the concept of "raison d'état" (reason of the State) promulgated by Cardinal Richelieu, was deliberately transformed into "raison de nation" (Reason of the Nation). This anxiety over the fate of the nation, homeland and family caused a profound concern to anthropology, which found refuge in the umbrella of the authoritarian state that targeted the so-called internal enemies who collaborated with the external enemies!

The party state acted as an inquisition court that meted out its punishments in the alleged interest of all. In such circumstances, a blind conviction took root among two generations of anthropologists according to which the sole authority that protected people was the communist state. Hence, the prevalence is even today of the simplistic meaning of the relationship man-state. It is difficult for people to take his or her share of responsibility and try to do their bit. Even today there are people who say "The state should have mercy" or "the leader should turn his eyes towards us and solve our problems"! The Albanian individual anthropos has traditionally been an oral type. This is so by virtue of the fact that for a very long period of time, the Albanian language was only spoken, not written. Furthermore, until the end of the Second World War, over 90 percent of the people were illiterate. Hence, our anthropology did not cultivate the habits of learning and knowledge, or of communication with theoretical arguments. There are no debates held over references to various academic authors or scientific theoretical schools. Transmission of words, with everyone adding something from personal imagination and interest, is a general clime of life in the Albanian anthropological reality to our days. We are faced with an anthropology that absolutely likes to use readymade words uttered in the form of propaganda by the leaders or the authorities, be them national or international. It seems as if people are unwilling to turn to their personal conscience and give personal replies. Delegation of sovereignties to authority and failure to bear individual responsibility for them is still a way of life for a large number of people in our anthropological reality! There is a lack of civic education of cooperation with the institutions. Communication with powerful individuals is the preferable way. This negative patrimony has its roots not only in the totalitarian communist society, but even in earlier times in our national history. Lack of institutional democracy is one of the major gaps that have accompanied Albanian anthropology in all its history.

Relationships were established with the totalitarian state or in its absence, with the customary code. We have very little history of institutionalization and a whole history of striving to survive as a people and nation. This is why even to our days; individuals demonstrate more a militant energy than institutional cooperation energy.

In the communist society, "propaganda was built in such a way as to highlight only the values and authority of the senior leadership, and in particular, of the leader. People were comfortable with demonstrating a profound, almost blind belief in the leader. Such a form of submission was family and tribal based. Individual psychic was transformed into an unidentified part of collective psychology. The climate of submission was built on and functioned under the authority of fear, which was institutionalized through special trials, police persecution, imprisonments and death penalties.

In conclusion, we may say that:

"In communism, the individual was deformed by extreme collectivism and sterile ideologization! For such an individual, love for the cause of communism was bred on the love for the regime. Such circumstances gave birth to "idol-ideology "and "idol-leadership". Such an education and moral gave birth and fostered the isolated and submissive individual, the class politicized individual, the individual who considered himself part of the army who had an epopee historic mission. The communist system of "Popular democracy" revived the earlier feature of our anthropology, formed during the period 
of Ottoman rule, that of serving and being ruled upon! So much so that individuals were competing with one another to serve the party and in the bottom up hierarchy to serve directly the main leader. Such form of competitiveness became rife in vices on account of the fact that due to cultural differences, the common part of anthropology operated under the impulse of negative energy, embodied in lies, slanders, intrigues, plots and hate. The need to serve revived the Ottoman mechanism of tutelage and belief on the basis of family, tribes, kiths and kin, regions and on nepotic links.

Regrettably this anthropological feature and this way of behaving are still present in the Albanian society, indeed with some worrying manifestations, since they are prevalent also among the younger generation. There are some youths who have graduated abroad and who, as soon as they join "the party scallions" and are encouraged to get state positions, begin to behave towards the higher leader of their party with shameful subservience. They parrot their speeches in first person so repetitively that they give you nausea and make you not want to listen to them. They do all of this buffoonery and unfurl their unscrupulous loyalty with the sole aim of winning the favors and drawing the attention of their leader and of demanding some official favors in return!

\section{The Transitional Period in Albania and the Misunderstanding of Freedom}

When the "Berlin wall fell and the domino process of the demise of communist regimes began in the entire East, Ramiz Alia, the last of the communist leaders in the country declared:

\section{"Albania does not belong either to the East or the West"! But where did Albania really belong?!}

"It had to be itself, an isolated human and natural environment where trespassing of state borders was paid with one's life and joining the world market through the taking of loans was considered state treason, and the culture of other peoples from western countries was stigmatized as ideological and moral degeneration ...People were limited in their individual thinking and in dreaming of having a personal life, in inspiring towards a broader world, free movement and visiting other countries even as tourists." These were the reasons why at the dawn of the 90s, we might describe the general picture as one of:"Extreme poverty, almost inquisitional-type isolation, outrageous class struggle, destruction of national economy for lack of funds, lack of freedom of religious beliefs, horrible prisons and deprivation of people of their freedom under Article 55 of the communist Criminal Code, which sentenced people for agitation and propaganda and so on. Such a reality had sowed general discontent among the entire society. Therefore when communism was toppled and pluralism became a reality with the creation of the Democratic Party, what struck one's eye was a chaotic mass of disoriented people drawn toward an anarchist energy, generated by the psychosis of discontent, which merged and vented out hatred over lost lives, abandoned fates, the anti-human misuse of life and its social guarantees." The attacks at that time focused only on some of the main leaders of the party and the state, some former Sigurimi members, and the judiciary. The rest of the people were involved en masse in the transforming movement of that time to build political pluralism. The PPSH was not disbanded, but was transformed into a socialist party. Those who had sang praises to the communist leaders and served with devotion to it became devoted followers of pluralist democracy.

Hence it is important to shed light on another fact that has left traces in the 20 year-old history of Albanian transition. Pluralism "was born from political converts. The communists were donned overnight as socialists, while anticommunists and arrivist communists woke up donned as democrats". Furthermore, even the nationalist and royal political parties set up during the Second World War were revived. "This is why anticommunism in Albanian transition was identified as democracy, anarchy as freedom, lack of rules as a right to change, and populism as supreme decisionmaking institution". At the beginning of the 90's, former minister of agriculture then, Mr. Petrit Kalakula, solemnly declared in parliament that,"It is better to be a fascist than a communist". It is about 20 years now that now and again the whole struggle or confrontation between the Democratic Party and the Socialist Party boils down to anti-communist and communist scheme. We hear such jargon like, "Bllokmen, sons of bllokmen"; "I will do to you what I did to your fathers", or more recently the use of the term, "oriental fascism"!

Despite the great assistance of Soros Foundation to set up the structures and build a mentality of open society (irrespective of some positive outcomes), we must regrettably admit that, "Albanian anthropology, with its anarchic concern and impatient, rigid, and unclear in its encounter with the democratic dream, adopted a very harsh stand toward freedom. It saw freedom as a game without frontiers, or as a cloak over the stoicism of an archaic fanaticism that preserved past traditionalism, where changes were accepted only with words, but in reality the impact of change was shallow and often not real. Just like in the past, a new reality and obligations stemming thereof are converted into an anthropological conscience through "crypto traditionalism", and as a result are manifested in the form of an individual, 
collective, family and tribal, and regional approach, which tries to pose as commitment to major changes required by the new economic and social system but which in reality continues to follow the same old anthropos-psychic schemes and anthropo-feudal behaviors. The energy of change is not yet an anthropo-institutional energy, energy of the rule of law and order. It is a pagan energy of confrontation, a combatant energy of conquests and even of taking one's life. Although 20 years of transition have elapsed, we have not yet created the mentality that considers freedom as our common home, with rules and regulations and institutional authority. It is still not understood that an open society is not a society with its doors flung to the wind for people to abandon their homeland en masse (as the case has been in the last two decades), but a society open to progress, self changes, investments in new values and finally as an attempt to build new economic and social policies, and religious, cultural and educational institutions.

The absence for a long time of freedom as a natural social requirement, as a mechanism of coexistence and instrument that broadens the limits of action under the law, whose aim is enhancement of human rights and their realization through human dignity and prosperity could not help leaving its imprint in the individual and collective conscience. The long historical authoritarianism and permanent lack of democracy as a system, the frightening isolation during communism, the absence of all forms of private ownership, lack of freedom of expression, including the religious freedom, reduced Albanian individual anthropos to a totally deformed state quite unprepared for liberal democracy.

The liberal democratic society with its rules and proven structure and content in the developed western countries, (which of course did not occur overnight) was coming as a historical burden for a feudal anthropology like the Albanian one which had the mob and its leaders as its basic structure. This was so because Albania had not passed the period of bourgeois and capitalist system. This is why the downfall of communism in the former communist countries of the East could more easily adjust itself to the bourgeois past and civil traditions of that system. Since in Albania there was no such a past historical and political reality, it was necessary to place the corner stones in order to build the new edifice of "institutional democracy". To the royal period that lasted only ten years can be attributed the historic contribution of transforming the tribal society into an administration society. This is why at the outset of the $90 \mathrm{~s}$, when communism fell, the procommunist past did not offer any bearings, the present was rationally impossible to know, while the future could not be scientifically foreseen. As Mr. Sali Berisa declared in December 2010, on the occasion of the $20^{\text {th }}$ anniversary of the emergence of democratic movement in Albania, "The gates were flung open, but we did not know which road to take".

This entire situation gave rise to anarchy as a manifestation of incapacity to find our bearings. The anthropoanarchy was created as a transitional form of anthropological groups, By deviating from the class and ideological forms of communist organization and in their contact with the free market economy, the freedom of movement, and a society open to change, being unprepared and guided by an incapable politics, our anthropology assumed intermediary forms, illusive shapes, and unstable structures. Anthropo- anarchy embarked on a battle to justify its existence by forcing the state through its decrees to perpetuate anthropological informal practices in the field of ownership and economy, paving thus the path to the emergence of anarchic individual as promoter of the transitional Albanian society! Politics accepted this dictate on account of the votes it got from such individuals and groups who represent a large number of voters all over the country! Unlike all the other former communist countries, Albania was the only country in Europe that has problems with informal ownership on a national scale.

As a matter of fact, the government is more willing to legalize informal ownership than to support by law and administrative decrees the lawful owners. About 300,000 unlawful constructions are in a process of legalization all over the country! The people who have produced such a high level informal ownership are mostly the voters and less so members and sympathizers of the political parties. Such a large scale informal reality is present only in Albania and in no other former communist country. If we take into account the ancient saying that property is $9 / 10$ law and $1 / 10$ asset, then it is clear that such a level of informal ownership is an assassination to the rule of law. Such a situation helps one understand why "democracy through the rule of law" is not functioning here"!

Export of democracy based on the Copenhagen criteria has resulted in its structural implementation in Albania. However, the reform of the legal and administrative system is not sufficient to create an anthropology imbued with the civil values and oriented towards law and order. For the principle of "first rules, and then freedom" to be rooted in the anthropological conscience, it is necessary that along with institutional reforms, Albanian society should have first engaged in a process of mental and spiritual revival of traditional anthropological ritual, and theoretical and moral training and education in democracy as a life philosophy! 


\section{The Features of Political Pluralism in Albania}

In Albania there is party pluralism but no political pluralism. It may seem as if such a statement makes no sense, but it is a fact of life that political coexistence is not grasped and is not used as a basis for common actions through diversity and programs. The essence of cultural pluralism, which means equal through diversity, is not accepted! In the last 20 years, the ruling and the opposition parties have not seen themselves as complementary forces that should cooperate to draft the national strategies of development even through making constructive criticisms or presenting alternative solutions. At present there are some 50 political parties, but they do not justify their existence by doing any credit to the social and political state and groups of followers they represent or the interests of the Albanian society. Most of these parties have emerged as a result of inside squabbles and conflicts underlined not by principled interests, but by the deflection of certain individuals or groups discontent with the political parties. The chairmen of the big or small political parties upon taking the party posts devote all their energies resorting to intrigues and unprincipled struggle with the sole motive of holding their posts.

The Social Democratic Party has been led from its foundation by Skënder Gjinushi. Three other smaller parties have derived from it. The Liberal Democratic Party led by Arian Starova; the Social Democracy Party is led by Paskal Milo, while another party is led by Gaqo Apostoli. The Social Democratic Party is among the first political parties established in pluralism in Albania and the first political force that became member of "Socialist International". At present it is not represented in the Albanian Parliament. The same was true of the Socialist Party. Initially it was llir Meta and his group that broke away from it and formed the Socialist Movement for Integration (LSI), and then it was Petro Koçi who deflected from it and formed the Socialist Party 99.

It is no wonder that we see a further break up of this party. The same happened with the Democratic Party led by Mr. Sali Berisha, which gave birth to some right and left center parties. Indeed, even nationalist parties dating back to World War II like "Balli Kombëtar- National Front "and the Royalist Party have broken up into other parties. All these small and very small parties want by all means to be represented in parliament and possibly also in the government at central and local level. Their members pass from one political grouping to another even to a quite different political allegiance with the sole aim of benefiting something. Such a fragmentation of partitism has given rise to a very irregular and not at all functional political pluralism, where each wants to get a share of the political cake. A deformed political landscape has been created with a distinct medieval anthropological shape.

The two largest political parties, the Socialist Party and the Democratic Party resemble two large pashaliks, one representing the South and the other the North. The SP is popular and with authority over the people of the South, the Tosks, and the DP, popular and with authority among the Gegs. The small parties look like feuds, gates of medieval selfproclaimed princes. There are also parties that are reminiscent of crazy medieval knights who go to war as mercenaries and to plunder, without giving much thought to who they serve and against whom they fight.

Political parties in Albania, big or small, are based on "region- based links". Thus the DP is seen as the party of the "Tropoja people" from where Mr. Berisha is. The ordinary people of this party look upon Mr.Sali Berisha as the son of their region, as the historic representative of this geographical space, as a leader or god that has come to this post to defend them and their interests. The SP is the party of the southern people, the southern geographical space covering the area of Vlora, Tepelena Gjirokastra, and others. Their leader should be only from that area. In the high leadership of this party, there is not a single individual from the northern part of the country with the exception of Namik Dokle, present in this party from the time of the Party of Labor of Albania (PPSH). The party of llir Meta is the party of people from Skrapar, the region from where Meta is.

The Christian Democratic Party led by Nard Ndoka is the party of "Great Highlands", the region from where Mr. Ndoka is. Within the political parties, their structures, especially in the suburban and rural areas where more than half the population lives, are based on family and tribal and even regional links. The mechanism of "anthropological incest" is so to speak at play here, as Erich Fromm describes the links based on blood relations, which come down to us as a medieval ritual. In such mechanisms, nepotism is flourishing. When the Gerdec tragedy occurred, where 26 innocent people lost their lives in a makeshift dismantling munitions plant, the then Minister of Defense Mr. Fatmir Mediu handed in his resignation. He represented the Republican Party. It was precisely at that moment that Mr. Sabri Godo, a writer by profession, made use of that situation to ensure that his daughter join the government as representative of the Republican Party in the capacity of minister of health.

Political pluralism in Albania is non functional even when there are coalition governments in place. Each minister in every department pursues policies of his or her party. When Albania was admitted a NATO member, the then minister of defense declared that the Republican Party that he chaired had rendered a major contribution to Albania's membership in 
NATO. When the Albanian citizens were accorded visa liberalization to travel to the Schengen area, we heard such statement that it was the DP that liberalized the visa regime.

"Fragmentation" of politics is a typical expression of a medieval mentality.

Partitism in Albania continues to project the state, the institutions, and the public administration as a philosophy of management, as morality, and as employed partisan anthropology. When a political party comes to power, it assumes all state prerogatives and treats the opposition and the civil society merely as spectators that should only applaud it. There was indeed even an initiative, which was never officially declared, to sign a pact between the PS and the PD, on the basis of which when one of them was in power; it should have a free hand to do what it deemed appropriate based on its philosophy, without being impaired by the opposition. This attitude towards the state and power indicates a "double monocracy". In other words, what in the conditions of the "party state" was done by a single political party now is done by two political parties. Thus "pluralist authoritarianism" has become "spotted" now (round large parties revolve smaller parties). Democratic pluralism based on western style institutional civilization has still a long way to go.

Another feature of political parties in Albania is the fact that all the parties have been targeted by the man with market interests, by the homoeconomicus! Their life and mission has become a market commodity, since adherence to such parties is seen mostly as a possibility for economic gains, for capturing leading positions in the central and local power or in the public administration. The posts linked with the management of public funds are preferred.

Such a type of "capitalism of political parties" preferring ownership of national assets and public or community properties has brought about a "rapacious capitalism", as George Soros describes it. The manifestation of the clearly defined "business-partitism" has transformed the political parties into market accessories, whereas the confrontations within them, into confrontations for economic and business interests, far from debates over ideas and program alternatives. Partitism has become a market accessory. The worst thing about it is that this mechanism has become the system, so in Albania there is no poor politician. Another feature of party pluralism is lack of party relativism. The parties sell their ideas and programs as absolute truths. In such circumstances, it is impossible for cultural political pluralism to function. This is why democracy in Albania cannot be called functional, but it cannot be called simply fragile either! It is an authoritarian democracy that is nurtured by the philosophy of exclusion and conflicting actions and the Ottoman spirit of "severed heads"! It is therefore necessary that changes to create a system of liberal democracy begin with love for rule of law and constitution! We must pass from oriental mentality to western mentality!

\section{References}

Përparim Kabo,"Autoritarizëm në Tranzicion"-Antropologjia shqiptare përmes globalizmave. ISBN 99943-903-2-5, Botimi parë tetor 2006. Shtëpia botuese Plejad "Authoritarianism in Transition"- Albanian anthropology through globalization. First Edition October 2006. Publishing house-Plejad; ISBN 99943-903-2.

Përparim Kabo,"Antropologji pa sistem"-Feonomeni shqiptar mes psikologjisë dhe propagandës. Botimi viti 2001, shtëpia botuese Globus R. ISBN 99927-44-21-9. "Anthropology without system"- Albanian phenomena between psychology and propaganda. First Edition 2001. Publishing house Globus R; ISBN 99927-44-21-9.

Stephanie Schwandner-Sievers and Bernd Fischer -editors"Albanian Identities"-Myth and History.Hurst \& Company, London, www.hurstpub.co.uk, ISBN 1-85065-572-3.

Fareed Zakaria "The Future of Freedom the Illiberal Democracy at Home and Abroad, W.W.Norton \& Company, New York - London, 2004. Albanian version, ISBN 978-99956-668-0-4, publishing by Institute for dialogue and communication.

Enver Hoxha, "Kur u hodhën themelet e Shqipërisë së Re" Shtëpia Botuese "8 Nëntori" Tiranë 1984. "When the foundation of the new Albania". Publishing house "8 Nëntori." Tirana 1984

Aleksandër Meksi,"Dhjetor 90"-Dokumente\& Materiale, UET Press, 2010, ISBN 978-99956-39-40-2 “December 90"- Documents \& Materials. UET Press,2010.

Paolo Rago, "Tradizione, nazionalismo e comunismo nell'Albania contemporanea." "Tradition, nationalism and communism in Albania contemporary", Copyright 2011, edizioni "Nuova Cultura", Albanian version,"Tradita, nacionalizmi dhe komunizmi në Shqipërinë e sotme" ISBN 978-99943-0-211-5

Peter Bartl,"Albanien: vom Mittelalter biz zur Gegenwart Regensburg:Pustet 1995 Copyright -Verlag Friedrich Pustet, Regensburg, "Albania: from the Middle Ages to the present.", Albanian version, Shqipëria nga Mesjeta deri në ditët tona", ISBN 978-99943982-87.

Henry Kissinger-"Diplomacy.", Albanian version "Diplomacia” ISBN 99927-634-0-x The publishing house of the Writers. Tirana Year 1999.

The Crisis of Global Capitalism (Open society Endangered) Copyright 1998 by George Soros, Published in the United States by Public Affairs TM, a member of the "Perseus" Books Group. Albanian version,"Kriza e Kapitalizmit Global"; ISBN 99927-1-196-5

Joseph Stiglitz,"Making Globalization Work", Penguin Books, ISBN 978-0-141-02496-7 